\title{
Do Political Connections Decrease Financial Flexibility Reserves? Evidence from Chinese Private Firms
}

\author{
Zi-xu Liu \\ School of Accounting, Heilongjiang Bayi Agriculture University, China
}

Copyright $\bigcirc 2017$ by authors, all rights reserved. Authors agree that this article remains permanently open access under the terms of the Creative Commons Attribution License 4.0 International License

\begin{abstract}
This paper examines the impact of political connections on financial flexibility of private firms in China. Using a nationwide survey of Chinese private firms, we find that political connections can decrease financial flexibility reserves when financial constraint, environmental uncertainty and other variables are controlled. We further find that the high strength of political connections decreases more financial flexibility reserves than the low strength of political connections does.
\end{abstract}

Keywords Political Connection, Financial Flexibility, Private Firm

\section{Introduction}

Financial flexibility is one of the most important determinants of financial decision-making [1]. It refers to a firm's ability of reacting to unexpected changes in cash flow or investment opportunity set in a timely and value-maximizing manner $[2,3]$. Firms maintain financial flexibility for two reasons: the uncertainty of environment and financial constraint. In the emerging economies, for example China, in contrast to state-owned firms, private firms are subjected to institutional discrimination and therefore encounter more serious scenario of uncertainty and financial constraint. As a consequence, it is more important for private firms to maintain financial flexibility than state-owned ones. Meanwhile, Chinese private firms also try to cultivate and build political connections with government which can lead to diminish institutional discrimination, improve external environment and obtain financial resources for development.

For private firms, both financial flexibility and political connection are purposely made-decisions in order to relieve of environmental uncertainty and purge the potential influence of financial constraint. Because of the motivation similarity of the two decisions, the following questions are aroused: What is the relationship between financial flexibility and political connections? Do political connections impact on financial flexibility decisions of private firms? Furthermore, do political connections decrease financial flexibility reserves of private firms?

Based on the Chinese private listed firms' data from 2004 to 2014, we screen out 6136 "firm-year" sample observations. By employing firm level cluster adjusted mixed OLS model, we empirically test the relationship between political connections and flexible financial reserves level. The study proves that in the case of private firms suffering institutional discrimination, political connections can decrease financial flexibility reserves level. The higher the strength of political connections is, the more decreasing amount acts on financial flexibility reserves. Our study contributes to the literature by offering a new perspective on the impact of political connectedness on the determinant of financial flexibility reserves of private firms in China.

The rest of this paper is organized as follows. Section 2 reviews the relevant literature and develops our hypotheses. Section 3 describes the data used in this paper and documents the research method. Section 4 presents and discusses the empirical results. Section 5 presents robustness check. Section 6 presents our concluding remarks.

\section{Literature Review and Hypothesis Development}

\subsection{Literature Review}

There are two strands of literature related to our study. The first strand studies the acquirement of financial flexibility. CFOs claim that financial flexibility has been considered as a first-order determinant of corporate financial policies [1, 4, 5]. Meanwhile, researchers find it hard to explain the reality of firm capital structure decisions by employing classical theories such as the trade-off theory and the pecking-order theory [6-8]. DeAngelo et al. [9] and Denis and McKeon [10] consider that many problems in which classical capital structure theories are violated stem from the neglect of the 
function of financial flexibility in financial decisions. And only when we fully weigh the valuation of financial flexibility in future financial decisions, could we effectively explain the phenomena, as we mentioned above, which appear to go against classical theories. Although the research on financial flexibility persists for a long time, there is still no uniform and authoritative definition of it. Nowadays the mainstream literature emphasizes on financial flexibility's function of "precaution" and "utilize" in the face of uncertainty environment. Deangelo and Deangelo [2] and Gamba et al. [11] argue that financial flexibility refers to the ability of a firm to timely obtain and employ financial resources so as to prevent and utilize uncertain events, and then grasp the valuable investment opportunities to realize value maximization. Deangelo et al.[2], the earliest literature to elaborate the access to financial flexibility, propose analyzing it through three aspects: cash flexibility, debt flexibility and equity flexibility. Firstly, concerning cash flexibility, Opler et al. [12] find that there is a positive correlation relationship between the degree of environmental uncertainty and cash holdings. Secondly, from the perspective of debt flexibility, Gamba et al. [11] and Byoun [3] manifest that low leveraged firms which remain debt capacity for a rainy day in the future can be a bailout for financial distress and seize investment opportunities in advantage of environmental uncertainty. Lastly, to the extent of Chinese reality, equity financing is strictly regulated and dividend is a half compulsory distribution system, as a consequence Zeng [13] argues that even the firms have equity financing capacity, it is still hard for them to obtain equity flexibility.

The second strand studies the impact of political connections on firm financial decisions. Political connection which initially originates from research on transition economic countries is defined as a kind of invisible relationship between firms and governments or politicians [14]. For example, Fisman [14] studies on political connections in Indonesia and finds that a sizeable percentage of well-connected firms' value comes from political connections. Then Faccio [15] finds that political connections are a common phenomenon by exploring data across 47 countries. Many studies manifest that political connections can bring a firm convenient financing channel [16-19], low taxation[20], easy industry access[21] and government subsidy [15,22]. Meanwhile, many studies document that political connections can cause a firm rent-seeking cost [23], excessive employment [23, 24] and innovation deficiency in science and technology $[25,26]$. To all hitherto existing literature, there are very few researches on the relationship between political connection and financial flexibility directly; however, some literature studies about the impact of political connection on cash holding level and debt level. Concerning cash holding, existing literature shows inconsistent conclusions from empirical analysis. Chen and Luo [27]argue that political connection can give rise to financing convenience for firms, so political connection is negatively related to the cash holdings. But with regard to agency problem, Boubakri et al [28] find that the politically connected firms hold more cash than those of non-politically connected. Concerning debt level, a large amount of literature manifests that political connections can significantly increase firms' debt level $[29,30]$.

All in all, there are mass literature studies on the relationship between political connection and the level of cash holding or debt, nevertheless few researches about the impact of political connection on financial decision from the perspective of financial flexibility, especially short of relative empirical research.

\subsection{Research Hypotheses}

As an emerging economy, Chinese private firms are confronted with two enormous obstacles: imperfect law environment and government's administrative interference. These two obstacles which often intertwine intricately give rise to negative institutional discrimination against private firms. Moreover, the institutional discrimination, on one hand induces serious environmental uncertainty, on the other hand leads to resource constraint on private firms, especially financial constraint. Therefore private firms, on the one side maintain a certain level of financial flexibility in financial field, on the other side positively cultivate and seek political connections in business field.

Financial flexibility is a sort of precaution and utilization ability in nature [13], which can provide resource support for firms to cope with violent environment changes as well as take advantage of them. The more serious the environment uncertainty and the greater the degree of financial constraint becomes, the stronger the firms' motivation to possess financial flexibility is $[2,3]$. Confronted with institutional discrimination which results in environment uncertainty and financial constraint, Chinese private firms heavily rely on maintaining certain level of financial flexibility reserves.

Meanwhile, a large number of private firms are cultivating and seeking political connections [22]. Political connection as non-productive activity is a sort of rent-seeking behavior in nature [23]. By keeping a special relationship with administrations or officials, political connections can alleviate the institutional discrimination against private firms and improve the environment uncertainty and financial constraint, which is bound to impact on financial flexibility decisions. As mentioned above, firms' holding financial flexibility is a financial guarantee measure which copes with environment uncertainty and financial constraints. Therefore, this study argues that Chinese private firms make use of political connections which are partially substituted for financial flexibility to alleviate environment uncertainty and financial constraints. Based on the discussion above, we propose the following hypothesis:

Hypothesis A: the private firms which have political connections hold much lower level of financial flexibility than those which have no political connections, that is to say, 
political connections can decrease financial flexibility reserves.

Meanwhile, the strength of political connections also impact on the decreasing amount of financial flexibility reserves. The higher the political status private firms obtain and the higher strength the political connections are, as a result, the stronger the degree of finance guarantee is and the more the amount of financial flexibility reserves decrease. Based on the discussion above, we propose the following hypothesis:

Hypothesis B: the high strength of political connections can decrease more amounts of financial flexibility reserves than those of low strength of political connections.

\section{Sample and Measurements}

\subsection{Sample and Data}

The initial sample consists of firm-year observations from the intersection of CSMAR and WIND databases over the period of 2004 to 2014. Our sample period starts in 2004, because China private list firm database in CSMAR have only become available since the year of 2004 . We then delete observations with missing data needed to calculate our financial flexibility variables and control variables. We also exclude firm-year observations which are in state of special treatment and belong to financial industry. After merging the financial flexibility and control variables with our political connections database, we are left with a final unbalanced panel sample of 6136 firm-year observations.

\subsection{Variables Measurements}

\subsubsection{Measuring of Financial Flexibility}

According to Deangelo et al. [1], there are three approaches to access to financial flexibility (FF): cash flexibility (CFF), debt flexibility (DFF) and equity flexibility. But the institutional environment of Chinese financing market proves that equity capital financing is strictly regulated and dividends are semi-compulsory. As a result, equity flexibility is negligible in China. We follow prior researches to gauge FF using sum of CFF and DFF $[1,13]$. Specifically, CFF, which refers to excess cash reserves of firm, is the difference between cash ratio of firms and cash ratio of industry mean value; DFF, which refers to residual debt capacity, is the difference between industry mean value of debt leverage and firm debt leverage. In robustness test, continuous variable $\mathrm{FF}$ is grouped by percentiles and then formed ordered data. According to the different percentile grouping, we define FF as ordered data variables QFFA, QFFB and QFFC respectively.

\subsubsection{Measuring of Political Connections}

We follow prior research $[22,31]$ to employ the political status of the actual controllers or chairmen of the board (general managers) as a proxy for political connections. Here political connections (PC) refer to the following five scenarios: former or current members of the People's Congress, former or current members of the Chinese People's Political Consultative Conference, former or current members of the Congress of Communist Party of China, former or current leaders of Association of Industry and Commerce, former public officials. If the actual controller or chairman of the board (general manager) fits one or more of the above five scenarios, the firm is defined as politically connected, here PC equals 1 , otherwise 0 .In order to examine the degree of influence of different strength of political connections on financial flexibility reserves, we further divide PC into high strength political connections (HPC) and low strength political connections (LPC).

Specifically, HPC, as a portion of PC, refers to part of the five scenarios mentioned above in which the political status of the actual controllers or chairmen of board (general managers) is national level or above (including) deputy provincial rank. For example, a firm is HPC when the actual controller of the firm is a member of the National People's Congress or former vice governor. Excluding HPC, we define political connections in other situations as low strength political connections (LPC). In the robustness test section, we employ politically connected firm actual controller (CPC) as a proxy for political connections. We also divide $\mathrm{CPC}$ into high strength of CPC (i.e. HCPC) and low strength of CPC (i.e. LCPC).

\subsubsection{Other Control Variables}

According to prior research, we control a set of firm characteristics that exist upon influence of the financial flexibility $[13,32]$. Specifically, we employ two important control variables: SA and Uncertainty, which stand for the degree of financial constraints and environmental uncertainty respectively, are the immediate causes of private firms' reserving financial flexibility. Here SA is a proxy for financial constraint following the research of Hadlock and Pierce [33]. We also control year-fixed effects and industry-fixed effects. The definition and description of variables are presented in Table 1. 
Table 1. Definitions of Variables

\begin{tabular}{|c|c|}
\hline Variable name & Definition \\
\hline $\mathrm{FF}$ & the sum of cash flexibility and debt flexibility \\
\hline QFFA/QFFB/QFFC & ordered data which is formed by grouping FF in percentiles, the details see 5.1 \\
\hline $\mathrm{PC}$ & $\begin{array}{l}\text { a dummy variable which equals } 1 \text { when the actual controller or chairman of the board is politically connected, otherwise } 0 \text {, } \\
\text { the details see } 3.2 .2\end{array}$ \\
\hline HPC & $\begin{array}{c}\text { a dummy variable which equals } 1 \text { when the firm possesses high strength of political connection, otherwise } 0 \text {, the details see } \\
3.2 .2\end{array}$ \\
\hline LPC & $\begin{array}{l}\text { a dummy variable which equals } 1 \text { when the firm possesses low strength of political connection, otherwise } 0 \text {, the details see } \\
3.2 .2\end{array}$ \\
\hline CPC & a dummy variable which equals 1 when the actual controller is politically connected, otherwise 0 , the details see 3.2 .2 \\
\hline HCPC & a dummy variable which equals 1 when the firm possesses high strength of CPC, otherwise 0 , the details see 3.2 .2 \\
\hline $\mathrm{LCPC}$ & a dummy variable which equals 1 when the firm possesses low strength of $\mathrm{CPC}$, otherwise 0 , the details see 3.2 .2 \\
\hline Uncertainty & standard deviation coefficient of latest 3 years of net profit ratio \\
\hline SA & -0.737 Size +0.043 Size $^{2}-0.040$ Age \\
\hline Size & logarithm of book value of assets \\
\hline Age & the years of being listed firm \\
\hline \multirow{2}{*}{ CashFlow } & cash flow from operating activities \\
\hline & total assets \\
\hline EPS & net profit \\
\hline \multirow{2}{*}{ ROA } & $\begin{array}{l}\text { the number of common shares } \\
\text { net income }\end{array}$ \\
\hline & $\overline{(\text { the beginning total assets }+ \text { the ending total assets for the period) } / 2}$ \\
\hline \multirow{2}{*}{ Casset } & the ending fixed assets for the period \\
\hline & the ending total assets for the period \\
\hline \multirow{2}{*}{ Growth } & net income for the period - net income of previous period \\
\hline & net income of previous period \\
\hline \multirow{2}{*}{ Investratio } & construction in process of previous period \\
\hline & total assets of previous period \\
\hline HHI & sum of squares of the top 5 shareholding percentage \\
\hline
\end{tabular}

\section{Regression Analysis}

\subsection{The Model}

In this section, following previous approach, we report the results of a multivariate regression analysis of the impact of political connection as well as firm characteristics on financial flexibility reserves. We adjust the standard errors for both heteroskedasticity in the error term and clustering of observations at the firm level. Specifically, we estimate the following model:

$$
\mathrm{FF}_{\mathrm{it}}=\alpha+\beta \mathrm{PC}_{\mathrm{it}}+\gamma \text { Control }_{\mathrm{it}}+\varepsilon_{\mathrm{it}}
$$

Here FF is the dependent variable which refers to the reserve level of financial flexibility; $\mathrm{PC}$ is a dummy variable which refers to political connections. In addition, $\alpha, \beta$ and $\gamma$ indicate intercept, coefficients of PC and control respectively. $\varepsilon$ is an error term. In order to limit the influence of extreme value, all continuous variables in the model are winsorized at the 1st and 99th percentiles.

\subsection{Summary Statistics of Variables}

Table 2 represents summary statistics of the main variables. The mean and median of financial flexibility (FF) are 0.237 and 0.197 respectively. These two positive numbers imply that Chinese private firms which have good awareness of the importance of financial flexibility generally reserve certain level of it. However, the minimum of FF is negative and the standard deviation is 0.321 , which means that the undulation of different sample is great. For Chinese private firms, the politically connected ones can reach up to $61.2 \%$, which preliminary confirms our judgment that the private firm has strong motive to seek for political connection in China. But the proportion of high strength of political connection (HPC) is only accounts for $11.6 \%$, and more than half of private firms are politically connected in low strength (LPC). The sharp contrast between HPC and LPC indicates that we cannot treat political connections without strength discriminations. 
Table 2. Summary Statistics

\begin{tabular}{|c|c|c|c|c|c|c|}
\hline Variable & $\mathrm{N}$ & Mean & Stdev. & Min & Median & Max \\
\hline FF & 6136 & 0.237 & 0.321 & -0.419 & 0.197 & 1.067 \\
\hline PC & 6136 & 0.612 & 0.487 & 0 & 1 & 1 \\
\hline HPC & 6136 & 0.116 & 0.332 & 0 & 0 & 1 \\
\hline LPC & 6136 & 0.494 & 0.500 & 0 & 0 & 1 \\
\hline Uncertainty & 6136 & 3.792 & 7.121 & 0.097 & 1.791 & 52.830 \\
\hline SA & 6136 & 3.630 & 0.947 & 1.651 & 3.495 & 6.810 \\
\hline CashFlow & 6136 & 0.0360 & 0.073 & -0.195 & 0.038 & 0.226 \\
\hline EPS & 6136 & 0.420 & 0.418 & -0.700 & 0.360 & 1.980 \\
\hline ROA & 6136 & 0.689 & 0.449 & 0.116 & 0.587 & 2.801 \\
\hline Casset & 6136 & 0.202 & 0.134 & 0.004 & 0.180 & 0.579 \\
\hline Growth & 6136 & 0.198 & 0.312 & -0.506 & 0.161 & 1.512 \\
\hline Investratio & 6136 & 0.042 & 0.057 & 0 & 0.020 & 0.285 \\
\hline HHI & 6136 & 0.161 & 0.101 & 0.014 & 0.140 & 0.478 \\
\hline
\end{tabular}

Table 3. Regression Results of Model

\begin{tabular}{|c|c|c|c|c|}
\hline Variables & $(1)$ & (2) & (3) & (4) \\
\hline $\mathrm{PC}$ & $\begin{array}{c}-0.088^{* * *} \\
(-5.491)\end{array}$ & $\begin{array}{c}-0.028 * * \\
(-2.073) \\
\end{array}$ & & \\
\hline $\mathrm{HPC}$ & & & $\begin{array}{c}-0.178^{* * * *} \\
(-8.236)\end{array}$ & $\begin{array}{c}-0.049 * * \\
(-2.313) \\
\end{array}$ \\
\hline LPC & & & $\begin{array}{c}-0.062 * * * \\
(-3.760)\end{array}$ & $\begin{array}{l}-0.022^{*} \\
(-1.647)\end{array}$ \\
\hline Uncertainty & & $\begin{array}{c}-0.003 * * * \\
(-3.655)\end{array}$ & & $\begin{array}{c}-0.003 * * * \\
(-3.571)\end{array}$ \\
\hline SA & & $\begin{array}{l}-0.135 * * * \\
(-17.828)\end{array}$ & & $\begin{array}{c}-0.132 * * * \\
(-17.146)\end{array}$ \\
\hline CashFlow & & $\begin{array}{c}0.403 * * * \\
(6.395)\end{array}$ & & $\begin{array}{c}0.407 * * * \\
(6.475)\end{array}$ \\
\hline EPS & & $\begin{array}{c}0.238 * * * \\
(15.789) \\
\end{array}$ & & $\begin{array}{c}0.238 * * * \\
(15.814)\end{array}$ \\
\hline ROA & & $\begin{array}{c}-0.120^{* * * *} \\
(-6.530)\end{array}$ & & $\begin{array}{c}-0.120^{* * *} \\
(-6.544) \\
\end{array}$ \\
\hline Casset & & $\begin{array}{c}-0.558 * * * \\
(-11.148)\end{array}$ & & $\begin{array}{c}-0.555^{* * *} \\
(-11.043) \\
\end{array}$ \\
\hline Growth & & $\begin{array}{c}-0.075 * * * \\
(-5.745) \\
\end{array}$ & & $\begin{array}{c}-0.076 * * * \\
(-5.773) \\
\end{array}$ \\
\hline Investratio & & $\begin{array}{l}-0.0220 \\
(-0.294) \\
\end{array}$ & & $\begin{array}{l}-0.0250 \\
(-0.330)\end{array}$ \\
\hline HHI & & $\begin{array}{c}0.310 * * * \\
(4.955)\end{array}$ & & $\begin{array}{c}0.312 * * * \\
(4.990)\end{array}$ \\
\hline intercept & $\begin{array}{l}0.0810 \\
(1.640)\end{array}$ & $\begin{array}{c}0.636^{* * * *} \\
(8.736) \\
\end{array}$ & $\begin{array}{l}0.102 * * \\
(2.079)\end{array}$ & $\begin{array}{c}0.632 * * * \\
(8.807) \\
\end{array}$ \\
\hline No. of observations & 6136 & 6136 & 6136 & 6136 \\
\hline adjusted $\mathrm{R}^{2}$ & 0.151 & 0.443 & 0.165 & 0.443 \\
\hline
\end{tabular}

\subsection{Regression Results and Analyses}

Table 3 reports the regression results of China private firms' financial flexibility reserves on their political connections. In column 1 and column 2 we employ PC as a proxy for political connections to examine Hypothesis A. The coefficients of main explanation variables (PC) in column 1 and 2 are all significantly negative, which verifies Hypothesis A, that is, the political connections can decease financial flexibility reserves. In order to investigate the degree of influence of different strength of political connections on financial flexibility reserves (Hypothesis B), in column 3 and column 4 we divide PC into two variables: high strength of political connection (HPC) and low strength of political connection (LPC). The coefficients of main explanation variables (HPC and LPC) in column 3 and 4 are significantly negative and the absolute value of HPC's coefficient is higher than that of LPC. Furthermore we execute "lincom" order in STATA and find that the value differences between HPC and LPC in column 3 and 4 are at $1 \%$ and $10 \%$ significance level respectively. This verifies Hypothesis B which shows that the high strength of political connections can decrease more amounts of financial flexibility reserves than those of low strength of political connections. 
Table 4. Regression Results of QFF

\begin{tabular}{|c|c|c|c|c|c|c|}
\hline \multirow{2}{*}{ Variables } & \multicolumn{2}{|c|}{ QFFA } & \multicolumn{2}{|c|}{ QFFB } & \multicolumn{2}{|c|}{ QFFC } \\
\hline & (1) & (2) & (3) & (4) & (5) & (6) \\
\hline \multirow{2}{*}{$\mathrm{PC}$} & -0.0860 & & $-0.115 * *$ & & $-0.151 * * *$ & \\
\hline & $(-1.52)$ & & $(-2.15)$ & & $(-2.91)$ & \\
\hline \multirow{2}{*}{ HPC } & & $-0.255^{* * *}$ & & $-0.259^{* * *}$ & & $-0.318^{* * *}$ \\
\hline & & $(-2.78)$ & & $(-3.01)$ & & $(-3.80)$ \\
\hline \multirow{2}{*}{ LPC } & & -0.0600 & & $-0.091 *$ & & $-0.114 * *$ \\
\hline & & $(-1.05)$ & & $(-1.66)$ & & $(-2.16)$ \\
\hline \multirow{2}{*}{ Uncertainty } & $-0.010^{* *}$ & $-0.010^{* *}$ & $-0.016^{* * *}$ & $-0.016^{* * *}$ & $-0.017 * * *$ & $-0.017^{* * *}$ \\
\hline & $(-2.43)$ & $(-2.30)$ & $(-4.00)$ & $(-3.89)$ & $(-4.38)$ & $(-4.26)$ \\
\hline \multirow{2}{*}{ SA } & $-1.109 * * *$ & $-1.092 * * *$ & $-1.111^{* * *}$ & $-1.096^{* * *}$ & $-1.078 * * *$ & $-1.060 * * *$ \\
\hline & $(-30.25)$ & $(-29.24)$ & $(-32.59)$ & $(-31.52)$ & $(-33.07)$ & $(-31.84)$ \\
\hline \multirow{2}{*}{ CashFlow } & $2.491 * * *$ & $2.513 * * *$ & $2.564 * * *$ & $2.582 * * *$ & $2.498 * * *$ & $2.523 * * *$ \\
\hline & $(6.33)$ & $(6.39)$ & $(6.89)$ & $(6.94)$ & $(6.90)$ & $(6.97)$ \\
\hline \multirow{2}{*}{ EPS } & $1.850 * * *$ & $1.846 * * *$ & $1.779 * * *$ & $1.775^{* * *}$ & $1.809^{* * *}$ & $1.804 * * *$ \\
\hline & (21.76) & $(21.71)$ & $(22.61)$ & $(22.56)$ & $(23.72)$ & $(23.65)$ \\
\hline \multirow{2}{*}{ ROA } & $-0.725^{* * *}$ & $-0.726 * * *$ & $-0.785^{* * *}$ & $-0.787 * * *$ & $-0.806^{* * *}$ & $-0.808 * * *$ \\
\hline & $(-10.32)$ & $(-10.32)$ & $(-11.82)$ & $(-11.83)$ & $(-12.59)$ & $(-12.62)$ \\
\hline \multirow{2}{*}{ Casset } & $-3.975^{* * *}$ & $-3.947 * * *$ & $-4.267 * * *$ & $-4.245^{* * *}$ & $-3.968 * * *$ & $-3.942 * * *$ \\
\hline & $(-15.43)$ & $(-15.30)$ & $(-17.54)$ & $(-17.44)$ & $(-16.99)$ & $(-16.86)$ \\
\hline \multirow{2}{*}{ Growth } & $-0.685^{* * *}$ & $-0.688 * * *$ & $-0.599 * * *$ & $-0.600 * * *$ & $-0.584 * * *$ & $-0.585^{* * *}$ \\
\hline & $(-7.38)$ & $(-7.40)$ & $(-6.91)$ & $(-6.92)$ & $(-6.93)$ & $(-6.94)$ \\
\hline \multirow{2}{*}{ Investratio } & -0.448 & -0.468 & -0.326 & -0.345 & -0.229 & -0.249 \\
\hline & $(-0.89)$ & $(-0.93)$ & $(-0.69)$ & $(-0.73)$ & $(-0.50)$ & $(-0.55)$ \\
\hline \multirow{2}{*}{$\mathrm{HHI}$} & $2.161 * * *$ & $2.168 * * *$ & $2.284 * * *$ & $2.293 * * *$ & $2.267 * * *$ & $2.279 * * *$ \\
\hline & $(7.87)$ & $(7.89)$ & $(8.87)$ & $(8.90)$ & $(9.08)$ & $(9.12)$ \\
\hline \multirow{2}{*}{ cut1 } & $-4.363 * * *$ & $-4.346 * * *$ & $-5.013 * * *$ & $-4.995 * * *$ & $-5.183 * * *$ & $-5.151 * * *$ \\
\hline & $(-14.51)$ & $(-14.48)$ & $(-17.40)$ & $(-17.36)$ & $(-18.20)$ & $(-18.11)$ \\
\hline \multirow{2}{*}{ cut2 } & $-2.369 * * *$ & $-2.351 * * *$ & $-3.462 * * *$ & $-3.442 * * *$ & $-3.852 * * *$ & $-3.817 * * *$ \\
\hline & $(-7.99)$ & $(-7.94)$ & $(-12.18)$ & $(-12.12)$ & $(-13.68)$ & $(-13.57)$ \\
\hline \multirow{2}{*}{ cut3 } & & & $-1.854 * * *$ & $-1.835^{* * *}$ & $-2.678 * * *$ & $-2.642 * * *$ \\
\hline & & & $(-6.59)$ & $(-6.52)$ & $(-9.60)$ & $(-9.48)$ \\
\hline \multirow{2}{*}{ cut 4} & & & & & $-1.262 * * *$ & $-1.227 * * *$ \\
\hline & & & & & $(-4.55)$ & $(-4.42)$ \\
\hline No. of observations & 6136 & 6136 & 6136 & 6136 & 6136 & 6136 \\
\hline
\end{tabular}




\section{Robustness Check}

\subsection{Other Measure of Financial Flexibility}

In main model, financial flexibility (FF) is a continuous variable; instead, in robustness check we define financial flexibility (QFF) as a discrete variable. We group FF by different percentiles, and then define each group in accordance with the ordinal sequence; therefore we can form new ordered data. For example, we divide QFFA into 3 groups by $33 \%$ and $67 \%$ percentile. The first group is formed by the observations whose $\mathrm{FF}$ value is less than the FF value of $33 \%$ percentile. We make the first group equal 1(i.e. QFFA=1). The second group is formed by the observations whose FF value is between the FF value of $33 \%$ percentile and $67 \%$ percentile. We make the second group equal 2(i.e. QFFA=2). The third group is formed by the observations whose $\mathrm{FF}$ value is more than the $\mathrm{FF}$ value of $67 \%$ percentile. We make the third group equal 3(i.e. QFFA=3). And QFFB and QFFC are formed by the same method. The bigger the ordinal number is the greater the amounts of corresponding samples' financial flexibility reserves are. We employ this ordered logic model to check the main results and we find that the coefficient of main variables and the significance level are basically in accord with earlier findings(the details see table 4).

\subsection{The Political Connection of Firm Actual Controller}

In the main regression analysis, we define PC as politically connected actual controllers or chairmen of the board. For a private firm, as a matter of fact, actual controllers have absolute control over the firm; therefore the politically connected actual controllers are the pivotal role of checking the relationship between political connections and financial flexibility. We employ $\mathrm{CPC}$ variable into the regression analysis and the results are consistent with before, which provides further confirmation to the robustness of our conclusion (the details see table 5).

Table5. Regression Results of CPC

\begin{tabular}{|c|c|c|}
\hline Variables & (1) & (2) \\
\hline \multirow{2}{*}{$\mathrm{CPC}$} & $-0.024 *$ & \\
\hline & $(-1.77)$ & \\
\hline \multirow{2}{*}{ НСРC } & & $-0.046 * *$ \\
\hline & & $(-2.14)$ \\
\hline \multirow{2}{*}{ LCPC } & & $-0.0180 *$ \\
\hline & & $(-1.76)$ \\
\hline \multirow{2}{*}{ Uncertainty } & $-0.003 * * *$ & $-0.003 * * *$ \\
\hline & $(-3.64)$ & $(-3.55)$ \\
\hline \multirow{2}{*}{ SA } & $-0.135 * * *$ & $-0.133 * * *$ \\
\hline & $(-17.92)$ & $(-17.25)$ \\
\hline \multirow{2}{*}{ CashFlow } & $0.404 * * *$ & $0.408 * * *$ \\
\hline & $(6.41)$ & $(6.49)$ \\
\hline \multirow{2}{*}{ EPS } & $0.238^{* * *}$ & $0.238 * * *$ \\
\hline & $(15.80)$ & $(15.82)$ \\
\hline \multirow{2}{*}{ ROA } & $-0.119 * * *$ & $-0.120 * * *$ \\
\hline & $(-6.51)$ & $(-6.52)$ \\
\hline \multirow{2}{*}{ Casset } & $-0.559 * * *$ & $-0.556 * * *$ \\
\hline & $(-11.17)$ & $(-11.06)$ \\
\hline \multirow{2}{*}{ Growth } & $-0.075^{* * *}$ & $-0.076 * * *$ \\
\hline & $(-5.72)$ & $(-5.75)$ \\
\hline \multirow{2}{*}{ Investratio } & -0.023 & -0.0260 \\
\hline & $(-0.30)$ & $(-0.34)$ \\
\hline \multirow{2}{*}{ HHI } & $0.312 * * *$ & $0.313^{* * *}$ \\
\hline & $(4.98)$ & $(5.02)$ \\
\hline \multirow{2}{*}{ intercept } & $0.634 * * *$ & $0.631^{* * *}$ \\
\hline & $(8.69)$ & $(8.79)$ \\
\hline $\mathrm{N}$ & 6136 & 6136 \\
\hline adjusted $\mathrm{R}^{2}$ & 0.442 & 0.443 \\
\hline
\end{tabular}




\section{Conclusions}

Environment uncertainty and financial constraints which private firms are confronted with can be aggravated by constitutional discrimination. So maintaining a certain level of financial flexibility reserves and cultivating political connections are very important measures for private firms to extricate from financial predicament. Based on the private listed firms' data from 2004 to 2014, we screen out 6136 firm- year sample observations. By employing firm level cluster adjusted mixed OLS regression, we empirically examine the correlation between political connections and financial flexibility reserves. The paper demonstrates that the private firms who are politically connected maintain less financial flexibility on average than those who are not politically connected, i.e. political connections can decrease financial flexibility reserves. After distinguishing the strength of political connections, we prove that the high strength of political connections can decrease much more amount of financial flexibility reserves than those of the low strength of political connections.

Private firms as one of necessary components of China economy, prove increasingly important in economic development. However, China's market-supporting institutions are far from perfect; moreover, the institutional discrimination against private firms is never completely solved, both of which strongly motive private firms to build political rent-seeking and employ political connections. In this way private firms can obtain financial resource to substitute for financial flexibility reserves partially. In terms of China, private entrepreneurs' innovation activities are much more important and constructive than their rent-seeking activities. Therefore, administration should reduce direct control of financial resource, make market be the leading role in resource allocation, and promote market-oriented reform of financing market.

\section{Acknowledgements}

We are very grateful for the support of the Philosophy and Social Sciences Research Project of Daqing (NO.DSGB2017108).

\section{REFERENCES}

[1] Graham J R, Harvey C R. The Theory and Practice of Corporate Finance: Evidence from the Field. Journal of Financial Economics, 2001, 60(2): 187-243.

[2] Deangelo H, Deangelo L. Capital Structure, Payout Policy, and Financial Flexibility. SSRN Working Paper, 2007.

[3] Byouns. Financial Flexibility and Capital Structure Decision. SSRN working Paper, 2011.
[4] Brounen D, De Jong A, Koedijk K G, et al. Corporate Finance in Europe: Confronting Theory with Practice. Financial Management, 2004, 33(4):1409-1442.

[5] Pinegar J M, Wilbricht L. What Managers Think of Capital Structure Theory: A Survey. Financial Management, 1989, 18(4):82-91.

[6] Frank M Z, Goyal V K. Testing the Pecking Order Theory of Capital Structure. SSRN Electronic Journal, 2000.

[7] Fama E F, French K R. Financing Decisions: Who Issues Stock?. Journal of Financial Economics, 2004, 76(3): 549-582.

[8] Myers S C, Still Researching for Optimal Capital Structure. Journal of Applied Corporate Finance, 2003, 6(1):4-14.

[9] Deangelo H, Deangelo L, Whited T M. Capital Structure Dynamics and Transitory Debt. Journal of Financial Economics, 2010, 99(2):235-261.

[10] Denis D J, Mckeon S B. Debt Financing and Financial Flexibility: Evidence from Pro-active Leverage Increases. Review of Financial Studies, 2011, 25(6): 1897-1929.

[11] Gamab A,Triantis A J.The Value of Financial Flexibility .Journal of Finance ,2008, 63(5):2263-2296.

[12] Opler T, Pinkowitz L,Stulz R, et al. The Determinants and Implications of Corporate Cash Holdings. Journal of Financial Economics, 1999, 52(1):3-46.

[13] ZengAimin, Zhang Chun, WeiZhihua.Financial Crisis Shocks, Financial Flexibility Reserve and Enterprise Investment Behavior: The Empirical Evidence of Listed Companies in China. Management World, 2013 (04):107-120.

[14] Fisman R. Estimating the Value of Political Connections. American Economic Review, 2001, 91(4):1095-1102.

[15] Faccio M. The Characteristics of Politically Connected Firms. Working Paper, West Lafayette: Purdue University, 2007.

[16] La Porta R, Lopezdesilanes F, Shleifer A. Government Ownership of Banks. Journal of Finance, 2002, 57(1):265-301.

[17] Mian A, Khwaja A I. Do Lenders Favor Politically Connected Firms? Rent Provision in an Emerging Financial Market. Quarterly Journal of Economics, 2005, 120(4): 1371-1411.

[18] Sapienza P. The Effects of Government Ownership on Bank Lending. Journal of Financial Economics, 2004, 72(2):357-384.

[19] Brown C O, Serdar Dinc I. The Politics of Bank Failures: Evidence from Emerging Markets. Quarterly Journal of Economics,2005,120(4):1413-1444

[20] Adhikari A, Derashid C, Zhang H, et al. Public Policy, Political Connections, and Effective Tax Rates: Longitudinal Evidence from Malaysia. Journal of Accounting and Public Policy, 2007, 25(5): 574-595.

[21] Bunkanwanicha P, Wiwattanakantang Y. Big Business Owners in Politics. Review of Financial Studies, 2007, 22(6): 2133-2168.

[22] YuMinggui, PanHongbo. The Relationship between Politics, Institutional Environments and Private Enterprises' Access to Bank Loans. Management World, 2008(8): 9-21. 
[23] Shleifer A, Vishny R W. Politicians and Firms. Quarterly Journal of Economics, 1994, 109(4): 995-1025.

[24] Barberis N, Boycko M, Shleifer A, et al. How Does Privatization Work? Evidence from the Russian Shops. Journal of Political Economy, 1995, 104(4): 764-790.

[25] Magee, S. P., Brock W. A., and L. Young. Black Hole Tariffs and Endogenous Policy Theory, Cambridge University Press, Cambridge, 1989.

[26] Baumol W J. Entrepreneurship: Productive, Unproductive, and Destructive. Journal of Political Economy, 1990, 98(5): 893-921.

[27] ChenYanyan, LuoDanglun. Macro-environment, Political Connection and Cash Holding. Finance and Trade Research, 2015, 26(4):131-140.

[28] Boubakri N, Ghoul S E, Saffar W. Cash Holdings of Politically Connected Firms. Journal of Multinational Financial Management, 2013, 23(4):338-355.
[29] Johnson S, MiltonT. Cronyism and Capital Controls: Evidence from Malaysia. Journal of Financial Economics, 2003, 67(2): 351-382.

[30] Houston J.R, Jiang L, Lin C, Ma Y. Political Connections and the Cost of Bank Loans. Journal of Accounting Research, 2012,52(1):193-243

[31] LiWeian, WangPengchen, XuYekun. Philanthropy, Political Connection and Debt Finance: Reciprocal Behavior of Governments and Private Enterprises. Nankai Business Review, 2015, 18(1):4-14.

[32] LiuMingxu, XiangXianhu. Environmental Uncertainty, Enterprise Characteristics and Financial Flexibility. Macroeconomics, 2014(4):127-134.

[33] Hadlock C J, Pierce J R. New Evidence on Measuring Financial Constrains: Moving beyond the KZ Index. Review of Financial Studies, 2010, 23(5):1909-1940 